\title{
New Zealand Winegrowers Attitudes and Behaviours towards Wine Tourism and Sustainable Winegrowing
}

\author{
Tim Baird ${ }^{1}$, C. Michael Hall ${ }^{1,2,3, *(1)}$ and Pavel Castka ${ }^{1}$ \\ 1 Department of Management, Marketing and Entrepreneurship, UC Business School, \\ University of Canterbury, Christchurch 8041, New Zealand; tim.baird@canterbury.ac.nz (T.B.); \\ pavel.castka@canterbury.ac.nz (P.C.) \\ 2 School of Business and Economics, Linneaus University, Nygatan 18B, 39234 Kalmar, Sweden \\ 3 Department of Geography, University of Oulu, FI-90014 Oulu, Finland \\ * Correspondence: michael.hall@canterbury.ac.nz
}

Received: 1 February 2018; Accepted: 10 March 2018; Published: 13 March 2018

\begin{abstract}
There are significant economic, environmental, social, and marketing issues that exist from the supply-side perspective in response to sustainability. This study examines New Zealand winegrowers in terms of their attitudes and behaviours towards wine tourism and sustainable wine production. A national survey was conducted at the end of 2015, which was the fourth such survey to be undertaken as part of a longitudinal study of wine tourism in New Zealand. This survey drew on issues of wine and biosecurity, climate change, and eco-labelling, as well as wine tourism. These issues were examined within the context of three key drivers of sustainability: the physical aspects of sustainable wine production, the internal drivers within wine businesses for the adoption of sustainable practices, and the external regulatory aspects that govern the adoption of sustainable wine production practices. The findings indicate that there were substantial concerns with the perceived value provided by both wine tourism and sustainable winegrowing practices. These concerns exist at both the firm level and with the governing bodies that are responsible for implementing sustainable winegrowing initiatives. Unless this perception of the value of sustainability within the New Zealand wine industry is altered in the future, it appears that there will continue to be an ongoing issue as to how sustainable winegrowing initiatives are implemented.
\end{abstract}

Keywords: wine tourism; sustainable winegrowing; rural development; regional development; biosecurity; branding; partial-industrialisation; innovation; climate change

\section{Introduction}

Even though wine, as well as wine regions and businesses, is often promoted in terms of its environmental attributes, winegrowing is an industrial process with resource use and waste. In addition to water and land use, winegrowing may also have substantial chemical inputs, such as biocides and fertilisers, and is also responsible for emissions-including from the transport of wine from the vineyard to the end consumer, who is often based in foreign markets-which are referred to as 'wine miles' [1]. The industrial dimensions of wine and its potential negative environmental externalities are distant from the portrayal of wine as an 'authentic' and 'natural' artisanal product. Nevertheless, there appears to be growing producer and consumer interest, including tourist interest, in sustainable wine [2]. As a result, many wineries and wine regions are not only seeking to make their wine production more sustainable, they are also looking to use sustainable practices as a point of brand and product differentiation in an otherwise congested and highly competitive market [3-5].

Although designed to promote a unified industry-wide benchmark for vineyards, wineries, and other wine businesses to strive to achieve their individual goals in terms of sustainable practices, the adoption of initiatives such as industry sustainability schemes are also valuable for their ability 
to be used in the promotion of wine products, as well as national and regional wine tourism and wine trails [6]. Winegrowing is often seen as an extremely important contributor to rural regional development because of its contributions to regional branding and significant employment opportunities [7]. Such perceptions are only enhanced by the direct-i.e., visits to wineries-and indirect-i.e., the purchase of local wine and food in restaurants—roles of winegrowing to tourism in such regions. Yet, the development of more sustainable winegrowing operations, including the role of wine tourism, is dependent not only on the size and economics of individual wineries, but also on the ability of wineries to deal with inherent risks that are borne from engagement with visitors to vineyards and wineries, such as biosecurity risks [8,9]. As a number of vineyards and wine regions have experienced, the introduction and spread of viticultural diseases and harmful vectors such as phylloxera and Pierce's disease [8] could potentially eradicate the work that has been done to encourage the adoption of sustainable practices and the innovations that may arise as a result of sustainability initiatives.

Wine tourism is defined as "visitation to vineyards, wineries, wine festivals, and wine shows for which grape wine tasting and/or experiencing the attributes of a grape wine region are the prime motivating factors for visitors" [10] (p. 1), and is increasingly used by winegrowers as part of their business strategy. This strategy not only provides an umbrella for the various revenue streams that wineries engage in (such as cellar door sales, accommodation, events, and wine and food festivals), it also encompasses a growing engagement with environmental issues such as biosecurity $[8,9]$ and sustainability [6,11-14]. Wine tourism has long been a source of added value for many vineyards and winegrowers [15-18]; it is also regarded as a brand differentiator that facilitates wineries meeting consumers face-to-face and thus enables a long-term relationship with a product that has been sampled at its place of origin $[17,19,20]$.

It has been suggested that there are three major benefits that are derived from cellar door sales, that of "distribution at low marginal cost, the development of brand equity, and the chance to add value" [21] (p. 7). Small wineries' tasting room facilities form an important part in the overall wine tourism marketing strategy by drawing consumers' attention towards the products available, which is then used to translate this attention into direct sales, making cellar door sales and/or winery visits potentially lucrative over the long term [22]. At the regional/destination level, the high profile of some wines and wineries that attract tourists can provide other regional businesses opportunities through association with a quality product [7]. Wine tourism can help differentiate a region's position in the tourism marketplace if it is connected with local wines, and it can also be integrated with broader branding strategies $[23,24]$. There is also some evidence that wine tourism can help extend the range of reasons for visiting a destination, extend the length of stay, and increase visitor expenditure on local products [7]. Therefore, rural regions in areas that are suitable for winegrowing often encourage the development of wine tourism and related activities such as food and cultural tourism [7,25].

New Zealand government statistics suggest that on average, $13 \%$ of all international holiday travellers visit a winery or participate in wine tourism activities annually in New Zealand, which is a figure well over 200,000 per year [26]. The market is lucrative, as international tourists participating in wine tourism spend NZ\$3700 compared to the NZ\$2800 average spend of all visitors. There is also a significant high value segment in the wine tourism market, with over $22 \%$ of international wine tourists claiming to spend over NZ\$5000 on their visit to New Zealand [26]. Significantly, $94 \%$ of international wine tourists are independent travellers, thereby reinforcing the capacity of such visitors to travel to rural regions, with their length of stay being significantly longer-with an average of 18.6 days-than the visitor average of 14.4 days [26]. Nevertheless, the bulk of winery visitors are domestic tourists, many of whom are day-trippers from urban centres, with the profile of the winery visitor varying according to the wine region, as well as the winery, as a result of locational and accessibility factors [27].

It is not without coincidence that the New Zealand wine industry has grown substantially since the 1980s along with international tourism [27]. Both industries have been central to New Zealand's brand positioning with respect to being 'natural', and their marketing efforts leverage off each other [28]. As of 
the end of 2016, the export value of the New Zealand wine industry was more than NZ\$1.57 billion a year. This figure is more than double that of 2007, reflecting high export growth [28]. As a result, the industry supports more than 16,500 full-time jobs along with substantial seasonal employment. However, the industry is not without major challenges; it is marked by substantial international competition and the vagaries of grape quality and tonnage are dependent on environmental factors such as the weather. In addition, there has been no change to per capita domestic consumption, meaning that the focus needs to be on exporting. Hence, wine tourism is valued as a means of generating market awareness and developing new customer relationships [28]. This means that the vast majority of wineries either have a cellar door where visitors can sample and purchase wines, or can be otherwise visited by appointment [27]. As of 2016, New Zealand had 675 wineries, which is more than the 130 that existed in 2007, but down from the high of 703 in 2012 [28]. The number of growers has declined from a high of 1117 in 2009 to 747 in 2016, although the total area under grapes has grown from 31,964 ha to 36,192 ha over the same period. The average area of the 2040 vineyards in the country was 17.4 ha, with production being dominated by Sauvignon blanc, which accounts for around $60 \%$ of all of the area under wine grapes, and $74 \%$ of all white wine production. Red wine is similarly dominated by a single variety, with Pinot noir accounting for $70 \%$ of red wine production [28].

Naturalness and sustainability have become drivers of New Zealand's tourism and wine branding, and are also inherent in national branding $[29,30]$. New Zealand Winegrowers, the peak industry body, have placed a premium on the importance of sustainability, with their 2016 Annual Report stating, "The sustainability story of New Zealand wine is being shared with wine influencers and consumers around the world" [28] (p. 19). However, despite the importance attached to sustainability at a national level, there is relatively little known about sustainable behaviours and attitudes at the winery level. This is an important issue, given that wineries have a significant role in both the wine and tourism industries [29]. Therefore, using a national survey of wineries, this paper provides insights into winery understandings of sustainability, and their behaviours. It is divided into four main sections. First, the remainder of the introduction will provide an overview of the issues that are associated with winegrowing and sustainability. Second, this paper will provide an account of the survey instrument. Third, the results of the survey will be provided, and, finally, this paper will conclude with the insights that can be drawn from the research and their implications for understanding sustainability in the wine tourism and winegrowing context.

\subsection{Sustainability Issues within the International Wine Industry}

Although Ohmart [31] writes of a synchronicity that can be achieved when the goals of sustainable winemaking practices are in tandem with both the local community and the natural environment, the development of sustainable winegrowing presents a number of challenges to wine production and marketing practices [1,32-42]. Not only have there been changes made to production methods, but also the move towards sustainable practices within the wine industry has created several significant issues. The first issues regards the adoption, implementation, and governance of these practices. The second issue concerns how these sustainable practices are promoted in terms of brand positioning and competitive advantage. The final issue relates to whether sustainable winegrowing represents a pathway towards long-term economic viability for wineries.

\subsubsection{Sustainability from Stakeholder Perspectives}

The recognition of the importance of sustainability issues occurs at multiple levels that are both internal and external to the winery concerned [32,43]. Many stakeholders perceive sustainability as an important source of competitive advantage that can transfer into a positive, environmentally conscious image in the mind of the consumer, resulting in increased sales and brand loyalty [44]. However, wine producers face an extremely competitive business environment given a decline in per capita wine consumption, the increased internationalisation of wine sales, and changes in consumer taste [1]. 
The knowledge that stakeholders possess regarding environmental issues is also an important factor that is associated with their involvement concerning environmental issues; this can be carried forward into the subsequent purchase behaviours and brand loyalty towards particular wineries [44].

The adoption of sustainable practices as a point of differentiation has been noted as a growing trend among wineries $[2,3,14,45-49]$. The way in which the end product reaches consumers has become important when considering environmental issues such as carbon emissions and the food/wine miles that are undertaken in the journey from the vineyard to final consumption [44]. Attracting wine tourism (winery visitation) via the promotion of sustainable methods of onsite viticultural production is another path that is being used to pursue competitive advantage and build brand equity [44]. However, although this approach is undertaken in the interests of protecting the immediate environment, it does not always marry with the political and ecological realities of sustainability at a global scale [30]. Therefore, in order to be truly sustainable, wine growing needs to understand its environmental, social, and economic effects in the supply chain and distribution channels [45]. As a result, Barber et al. [45] (p. 167) suggest that "in order to increase purchase intention of an environmentally responsible product, such as visitation to ecological wine regions, consumer promotion should address both environmental and individual product consequences".

Economies of scale are critical to the implementation of sustainable practices. In a study of sustainable viticulture practices in California, it appeared that the larger wineries had the resources and financial means to pursue their locally-based sustainability program, while smaller vineyards that were less financially empowered had a slower rate of adoption [50]. Shaw et al. [51] (p. 1091) put forward the idea that the three social processes of "innovation, cultural change and co-operation" are critical to the adoption of sustainable practices, based on their research in the Lodi wine region of California. Carmichael and Senese [3] add to this idea in their study of two contrasting Canadian wine regions (the Niagara Peninsula of Ontario and the Okanagan Valley of British Columbia), suggesting that the adoption of sustainable practices is also dictated by the business development stage of a winery. This scenario suggests a delicate balancing act; a proper balance creates synergy between the supply and demand forces at work in order to maintain a competitive and viable market position whilst also addressing political, economic, and ecological concerns $[3,30,50]$. In contrast, a lack of institutional support has hampered the adoption of sustainable practices by some Australian wineries: "In times of increasing environmental challenges and international competition, support from organisations that include government, local agencies, and industry associations is often needed to assist small winery operations and the wine industry in general in their quest for long-term environmental sustainability, while maintaining product quality" [52] (p. 168). Environmental protection and conservation practices are potentially an area of some contention within the industry; achieving a balance between national and firm goals and initiatives and approaches can be difficult to maintain. One example is the challenges that surround the management of biological invasions and disease [53]. Attempts to prevent the transmission of vector-borne diseases, which arguably present one of the highest level of threats to wine tourism, have been hampered by governmental and global management failures [54]. This in itself suggests that greater collaboration between government agencies and research institutions could provide a more coordinated approach [54].

\subsubsection{Biosecurity}

Key themes that have emerged in relation to winery biosecurity and invasive species concern the level of awareness among businesses of potential biosecurity risks, the strategies that are in place to deal with any such occurrences, and where wineries are able to turn in order to gain the information that they need to deal with and contain any problems that could potentially arise as a result of a breach of biosecurity protocols. For example, New Zealand Winegrowers have developed a biosecurity strategy, and entered into an agreement with the national government to share the cost of responding to biosecurity incursions. The Board of New Zealand Winegrowers also recommended the establishment of a dedicated biosecurity levy on winegrowers, although this levy "would normally be 
set at zero, and would only ever impose a cost on members if funds are needed for a major biosecurity response" [28] (p. 5). The approach of New Zealand Winegrowers illustrates that much of the concern of winegrowers with biosecurity is at a national border, rather than at the level of a vineyard, and with a focus more on rootstock and grafting standards rather than the movement of people [28]. There appears to be only limited awareness of biosecurity risks at the level of the wine tourist, who is coming into the country from a foreign destination, or even within countries [8,9]. However, these risks have been recognised as important by stakeholders within the wine industry elsewhere, such as for example in the Okanagan Valley of British Columbia [55]. While the wine tourism dimension is obviously very important, there are also biosecurity risks for winegrowers' vineyards even if they do not take visitors; therefore, the costs of any strategy and how they may be implemented are important considerations. In terms of risk mitigation, it has become of paramount importance to question whether vineyards have effective strategies in place to deal with potential biosecurity threats. A study of wine tourism in Oliver, British Columbia recognised the importance of strict biosecurity protocols and a high degree of information sharing regarding potential biosecurity risks. This study found that since community stakeholders viewed wine tourism as an important source of economic prosperity, protection from biosecurity risks that could be introduced by visitor traffic was therefore paramount from the stakeholder perspective [56]. However, biosecurity is arguably more of an emerging area in wine sustainability. Other environmental issues, such as the use and quality of water, organic and inorganic solid wastes, greenhouse gas emissions, and energy use tend to be given a higher priority in sustainable winegrowing, while the use of chemical products, land use, and broader ecosystem impact are other significant elements of concern $[11,34,45,57-59]$. Each of these issues will now be examined in turn.

\subsubsection{Water-Related Issues}

The use and quality of water is a significant factor in the wine production process [11]. Given the variability in geography, size, location, and production techniques that are applied during this process, it is usually the responsibility of each producer to ensure that most effective and efficient sustainable methods that are available are applied in terms of water use $[57,60]$. This situation represented a less than ideal scenario in a study of South African vineyard managers, where water usage was underreported by $60 \%$ of managers on average [61]. Australian vineyard managers have also been found to be underreporting water usage, to the point where $5 \%$ of cases studied were found to be using double the reported best practice level of $0.4 \mathrm{~L}$ per bottle [62]. A key issue in sustainable vineyard water usage is the lack of any formal benchmark that is based on the amount of wine produced versus the number of litres of water that are needed to meet what could be then labelled a truly sustainable wine production process $[35,57,62-64]$ The variety of geographical terrains that wine regions encompass dictates that the methods used, and the resultant efficiency of these methods, cannot be used as a basis for industry level benchmarks in terms of sustainable production $[35,57,63,64]$. In addition, the disposal of wastewater from winemaking and cellaring is one of the most pertinent environmental issues facing wineries that are attempting to adopt sustainable practices [58].

\subsubsection{Solid Waste}

Solid waste generation is a major issue facing sustainable wine production [45,52,65-67]. As a result, waste minimisation strategies have been a major focus of winegrowers' attempts to improve their environmental performance. However, the rudimentary ways in which waste minimisation strategies have been implemented by many wineries have resulted in an ineffective process for dealing with solid waste [68]. Organic waste in the wine production process includes byproducts such as grape marc, lees, pomace, stalk and dewatered sludge [57]. These all require specific disposal treatments due to odour issues [69]. Seasonal production variations also present a challenge to the management of wastewater quality, with the harvest period of production producing increased levels of effluent $[69,70]$. This challenge is often complicated by a lack of winegrower knowledge regarding organic waste 
production $[57,68,70,71]$. The methods that wine producers have utilised for inorganic waste disposal have been deemed even less effective than those used for organic waste [57]. Inorganic waste materials comprise "numerous kinds of waste plastic, especially pesticide containers, irrigation lines, old netting, vine guards, packaging waste and polythene" [11] (p. 994). The two most common types of disposal are incineration or depositing materials in landfill $[11,58,72]$, while recycling programmes have reportedly been met with only a limited degree of success [66]. The economic benefits of these methods of disposal have proven to be a contentious topic $[57,59,72,73]$, and it has been argued that stricter industry governance is required in order to ensure that all wineries follow appropriate waste disposal practices [71].

\subsubsection{Greenhouse Gas Emissions and Energy Use}

Studies that have examined the logistics involved in wine production and distribution have pointed out the intensive carbon footprint that these areas leave in terms of energy use [74-80]. This presents issues not only for winegrowers, but also for the entire supply and value chain all the way through to retailers, restaurants and consumers [1]. Over half of the carbon emissions involved in wine production occur in the post-production phase [81], creating substantial challenges in meeting the demands of the end consumer with regard to sustainability [82].

One industry response to the challenges posed by greenhouse gas emissions was the development of a joint initiative known as the Wine Industry Greenhouse Gas Accounting Calculator in 2007 [83]. Industry associations from around the world created this initiative in order to forge "a greater understanding of the carbon intensity of their own operations" [57] (p. 5). This need for a higher level of understanding is critical, as the increased temperatures that have resulted from climate change have the capacity to damage vines in a number of wine regions $[57,80,84]$.

\subsubsection{Climate Change}

The recognition of an "intrinsic link" between the climate in which wine grapes are grown and the quality of the wine that is produced [80] underscores the fragile nature of the wine industry in the face of global climate change. Winegrowing, similar to tourism, is an industry that is especially vulnerable to the effects of climate change, and "the wine industry is expected to be especially vulnerable to these impacts" [57] (p. 5). The potential impacts of climate change on winegrowing have resulted in a range of work that examines both the effects of climate change and the business response [80,84-91].

Traditionally, the warmest years have tended to produce the best wines in many regions [92]. However, this idealistic scenario is actually under threat, and may actually disappear altogether as "projected increases in average temperature and climate variability over the coming decades may threaten some regions' competitive advantage" [64] (p. 60). For example, regional warming in Northern California coupled with stress from frost, pests, and disease had led to the need to introduce adaptive measures such as ensuring that exposed fruit was provided with shade, delays in the start of pruning regimes, and the use of spray to protect grapes from UV rays [93].

When considered in the context of warnings of increases in the length of seasonal growth times, coupled with the advent of a greater number of extreme weather events, it would appear that the consequences of climate change could have repercussions throughout the global wine industry for many decades to come. Since "grape cultivars differ in their suitability for and adaptability to different climates, shifts in the cultivar profile of different regions, and possibly the emergence of hitherto unsuitable lesser-known or even novel cultivars, can be expected over the coming decades. A shift of grape production to cooler regions of the world i.e., towards higher latitudes and altitudes is [a] likely scenario of global warming" [64] (p. 64).

Nevertheless, the impacts of climate change are highly variable, both geographically and in terms of its effects on grape varieties $[84,85,91]$. Temperature changes in southern European regions have resulted in some areas becoming too hot to produce high-quality wines; as a result, some winegrowers have moved their operations to northern regions [84]. Similarly, research conducted in the Napa Valley 
region of California [94] indicated that the quality of grapes harvested was influenced by fewer frosts in the winter and the early onset of spring. The optimal conditions required for growing particular varietals are constrained to geographical locations. Therefore, climate change creates a situation that puts "the grapevines at a greater potential risk from climatic variations and change than crops with a broader geographic range" [84] (p. 322). One means of mitigating the economic risks of less than optimal growing conditions in the Niagara region of Canada has been to use weather contracts [95].

Strategies designed to address problems caused by climate change are regarded as critical within sustainable winegrowing in order to protect "the vitality of the industry" [93] (p. 484), as well as respond to wider pressures $[84,93,96,97]$. However, the capacity for a winegrowing or tourism system to be able to adapt to change is subject to the ability of actors to work collaboratively, as well as structural changes at the social and institutional level $[98,99]$.

\subsubsection{Chemical Use}

The use of chemical products in wine production has potentially become more prevalent as wineries attempt to pursue competitive advantage [69]. Chemical use is not solely related to just agricultural processes; it also occurs during the cleaning and maintenance processes for the equipment that is used in wine production [11]. Issues have arisen in terms of the use of chemically treated timber in vineyards, while the use of herbicides, pesticides, and synthetic fertilisers have also provided cause for concern [34,43]. This is because not only do these products present the risk of contamination to soil, they can also potentially jeopardise water sources as well [11,65].

The "inappropriate use of chemical products can devastate the vineyards' natural defence network by damaging [the] populations of natural predators that would usually keep the original pest at bay" [57] (p. 5). The lack of natural predators that this causes can lead to the application of stronger chemicals in order to boost vineyard defences, which can then potentially create even more environmental problems. The economic implications of increased chemical use have also resulted in a significant effect on the overall cost per tonne of grapes utilised in production [34,52]. Convincing wine producers to adopt natural approaches towards pest resistance has proven to be difficult, given that synthetic alternatives are more economical and less labour-intensive in their application [11,57]. The benefits derived from using natural approaches often only become apparent after the fact [52]; as a result, researchers have noted that "a significant challenge for future research will be quantifiably finding ways to articulate the economic and environmental benefit associated with natural approaches to viticulture and wine-related land management" [57] (p. 6). Indeed, biodiversity-oriented approaches to vineyard management practices are relatively uncommon [34], and sometimes result in unintended effects on local ecologies [84,100].

\subsubsection{Land Use}

Issues in terms of land management have come to the fore in recent years due to the rapid expansion of winegrowing regions; this holds particularly true for wine regions in New Zealand, Australia, and Canada $[43,59,65]$. The main problems concern the contamination, pollution, and perceived changes to existing environments $[43,45,59,67]$. It has been regarded as important that "wine organisations be able to tangibly demonstrate their commitment to environmental sustainability and preserving the local landscape" [57] (p. 6), as these problems also have the potential to damage relations with local communities. This underlines the importance of not just considering sustainable land usage solely from the point of view of the individual wine producers, but also taking community interests into account as well $[22,43,74]$.

\subsubsection{Consumer Responses to Sustainable Winegrowing}

Persuading growers to switch to sustainable winegrowing methods can require an assurance that there is something tangible to be gained in terms of the quality of wine, viability of the growing regime, and/or economic return. If this idea of tangibility is considered within the context of consumer 
perception towards sustainable winegrowing, there is relatively little literature to provide wine producers with evidence of the economic value of sustainable practices with respect to increased returns. A study of how sustainable production methods could be used by Californian wineries to differentiate their products found that "customers like the concept of sustainable winemaking ... but they really do not have a clear idea [of] what sustainability means in practice or what process the wineries do to achieve it" [50] (p. 193). A New Zealand-based study [34] also reported that while consumers supported the concept of sustainable winemaking, they had little knowledge of what exactly was involved in the production processes involved that gave the particular wine brands environmentally-based favourability.

Some authors have argued that strong environmental stewardship is necessary on the part of producers if the concept of sustainable wine production is going to be accepted and acted upon by wine consumers in their purchasing [101]. Forbes et al. [34] (p. 15) argued that "competitive advantage can only be gained in the marketplace if companies tell their consumers' about their environmental focus", and that greater emphasis should be placed on the labelling of wine products to reinforce awareness that sustainable wine production methods were used to create the end product. Nevertheless, the communication of the positive environmental attributes of sustainable wine products is an area where there appears to be a disconnect between the desire of firms to be seen to be taking a proactive approach towards sustainability, and the need for the end consumer to be able to access the appropriate information regarding what defines quality eco-certification at the point of purchase [34,102].

The question of whether eco-labelled wine can achieve higher price premiums in the marketplace has been a subject of some contention [34,45,50,74,102]. A study of American wine consumers found a willingness to pay more for environmentally-friendly wine packaging, and declared this to be a sign from wine purchasers that "our ecological problems are serious and that behaving in an ecologically favourable manner is important and not inconvenient" [74] (p. 439). However, when looking at this question from a supply-side perspective, a New Zealand wineries study [11] found that neither sustainable nor organic wines were able to obtain a price premium. The desire for a quality product, coupled with the personal values of those directly involved in producing the wine, were revealed to be the primary influences on improved environmental performance [11]. Consideration of these issues led to Jones [103] (p. 52) to comment: "While sound sustainability developments have occurred within the wine industry, it is becoming more and more critical to begin orienting the industry's innovation, communication and experiences toward consumer definitions, not solely industry definitions, of sustainability to ensure these efforts are relevant and promote economic vitality". This statement underlines an important area of concern for researchers on winegrower sustainability when contemplating whether or not firms actually value certification and view sustainability programmes that are aimed at achieving this as important or not. Clearly, if firms adopt a cursory approach to sustainability, then the implementation of branding and labelling initiatives will suffer as a result, with potential flow-on effects for brand and product perception.

\subsection{Sustainable Winegrowing Initiatives in New Zealand}

The evolution of industry-focussed initiatives to promote sustainable winegrowing within the New Zealand wine industry on a systemic basis began in 1995, with the development of the Sustainable Winegrowing New Zealand (SWNZ) organisation [104] as an initiative of the industry peak body. The SWNZ scheme was first introduced commercially in 1997 with the expectation that it would be adopted by winegrowers from all of the grape-growing regions nationwide. Coupled with the introduction of winery standards in 2002 [104], the scheme aimed to underline an industry-wide commitment to sustainable production practices and techniques. The goal of this initiative was to have full participation in the scheme by all New Zealand winegrowers by 2012, and steps to ensure this have been taken by making SWNZ membership mandatory for all wineries if they wish to take part in trade shows and export their products under the Wine New Zealand banner [104] (the brand of 
the New Zealand Winegrowers). Enforcement is also undertaken through the external auditing of sustainable practices by SWNZ-appointed agents [104].

The manifesto of SWNZ aims to provide a best practice model that wineries can utilise to benchmark their environmental practices [104]. These aims seek to provide a greater degree of quality during all stages of production, whilst also recognising that sustainability is an important issue to the end consumer, and affects whether they choose to buy wine produced in New Zealand [104]. This manifesto also encompasses five core strategies that are designed to provide benefits to all member of the scheme. These strategies are as follows [104]:

1. A framework of efficient and economical viticultural and winemaking practices that encourage environmental stewardship.

2. A continuous improvement pathway, enabling organisations to constantly improve and fine-tune their methods.

3. A knowledge-transfer platform for keeping up-to-date with new technology, approaches, and application techniques.

4. An external audit structure based on adherence to recommendations and guidelines issued by the OIV (International Organisation of Vine and Wine), with integrity and rigour to exceed market expectations.

5. The opportunity to play a part in preserving New Zealand's unique environment while operating under an independently audited and well-respected sustainability framework.

As membership of the SWNZ scheme is meant to be mandatory for all New Zealand wineries [105], applying such a framework in a standardised fashion to the New Zealand wine industry creates the potential for division should wineries reject the scheme's aims. When consideration is given to the number of vineyards exceeding the number of grape growers, it is pertinent to note that by the year ending October 2015, only 254 wineries, representing an estimated $37.7 \%$ per cent of New Zealand wineries at the time (Table 1), had actually become members of the sustainable wine-growing scheme. Commitment to carbon-neutral wine exports remained the focus of only a few, high-profile wineries [105]. So, based on this evidence alone, it would appear that there are some significant issues at play with the adoption of sustainability practices. Issues surrounding the adoption of sustainable winegrowing are not only limited to physical wine production elements; they can also affect the brand positioning of wine products and important avenues of offshore promotion such as wine tourism.

Table 1. Membership of Sustainable Winegrowing New Zealand (SWNZ).

\begin{tabular}{ccccccccc}
\hline & $\mathbf{2 0 0 4}$ & $\mathbf{2 0 0 5}$ & $\mathbf{2 0 0 6}$ & $\mathbf{2 0 0 7}$ & $\mathbf{2 0 0 8}$ & $\mathbf{2 0 0 9}$ & $\mathbf{2 0 1 0}$ & $\mathbf{2 0 1 5}$ \\
\hline Vineyards & 403 & 431 & 432 & 457 & 683 & 1244 & $\mathrm{n} / \mathrm{a}$ & 1918 \\
Number of wineries & 463 & 516 & 530 & 543 & 585 & 643 & 672 & 673 \\
SWNZ Wineries & 30 & 51 & 53 & 59 & 77 & 135 & 190 & 254 \\
\% membership & $6.5 \%$ & $9.9 \%$ & $10 \%$ & $10.9 \%$ & $13.2 \%$ & $21 \%$ & $28 \%$ & $37.7 \%$ \\
\hline
\end{tabular}

Source: Derived from New Zealand Winegrowers [105].

\section{Materials and Methods}

This study is based on the results of the 2015 New Zealand National Wineries Survey, which was designed to facilitate the collection of information about wine tourism in New Zealand from the wineries' perspective. The sample population was derived from all of the New Zealand wineries that were registered in the 2015 Australian and New Zealand Wine Industry Directory [106], and it was the fourth such survey of its type to be undertaken as part of a longitudinal study.

Based on the template provided by the three previous New Zealand National Wineries surveys $[13,27,107]$, survey questions were developed in light of the relevant domestic and international literature and fieldwork. The 2015 New Zealand National Wineries Survey was divided 
into seven main sections. The first two sections focused on the winery and visitor profiles. This was followed by sections dedicated to biosecurity and sustainability, as well as a section that examined innovation in the New Zealand wine tourism industry. The final section focused on tourism and marketing, and then led into a set of questions that were designed to gather respondent contact information. The generic questions in the 2015 survey with respect to winery profile and tourism were similar to those asked in the 1997, 2003, and 2010 surveys, with some modifications designed to gather updated information regarding sustainability and biosecurity.

The 2015 survey utilised primary data obtained from participants who represented each of the 558 wineries located within New Zealand from listings published in the 2015 Australian and New Zealand Wine Industry Directory [106]; these participants received the survey via post. A link was also provided for the winegrowers who preferred to complete the survey online. A total of 145 wineries responded (25.9\%). Of these 145 wineries, 80 responded that they had gone out of business, but these were still judged as valid responses, and these surveys were still included in the overall response rate. The remaining 65 winegrowers who responded provided the data that formed the basis of this study. Prior response rates to the 1997 survey obtained 111 responses out of 270 producers, giving a response rate of $41.1 \%$ [13,107], whilst the second survey conducted in 2003 achieved a response rate of 121 usable responses out of the 419 wineries surveyed, which provided a response rate of $28.9 \%$ [108]. The 2010 survey obtained 125 responses out of 511 producers (24.5\% response rate). Rates of response to this longitudinal survey compare favorably to other business surveys conducted within the New Zealand wine industry, such as a New Zealand Winegrowers-endorsed survey by Deliottes, which had a response rate of just 6\% from New Zealand wineries [109]. The corresponding 2017 survey sent to all members of New Zealand Winegrowers had "a record level of winery involvement" [110] (p. 1) with 45 wineries taking part, representing a very small increase in responses in percentage terms to the 2009 survey [109].

The determination of New Zealand wine producers' positions towards sustainable practices was the area in which the majority of new questions in the 2015 iteration of the survey occurred. These questions explored areas such as participants' commitment towards sustainable practices, whether such practices were viewed as being valuable as a potential source of competitive advantage, and the reasons sustainable practices were initially employed by the wineries that had chosen to adopt them. Questions posed in the biosecurity component of the 2015 New Zealand Wineries Survey were based on previous New Zealand studies of wine tourists and wineries $[8,9,27]$. As a result of the longitudinal nature of some of the survey questions, some responses are presented in comparison with previous iterations of the survey. Percentage summaries of responses to questions are provided in this paper, as are the mean Likert scores. In order to illustrate which factors are significant within the New Zealand wine industry, Levene's tests were also conducted where appropriate.

\section{Results}

\subsection{Cellar Door Sales}

In 2015, $81.5 \%$ of respondent wineries offered cellar door sales to the public, which was an increase from 2010, and a result similar to the 1997 figure (Table 2). The fluctuations in the availability of cellar door sales is potentially a reflection of the business turnover for smaller winegrowers, and issues faced by winegrowers with respect to business strategies and engagement in tourism as a revenue stream. Perhaps not surprisingly, $75.9 \%$ of respondents in 2015 believed that cellar door sales were significant for their business, which was a figure similar to the 1997 result. In contrast, only $65.9 \%$ agreed in 2003, and $57.2 \%$ agreed in 2010 . Significantly, respondents without cellar doors available to the public could potentially be visited by appointment. In order to ascertain whether there were particular characteristics that differentiated the wineries that offered cellar door sales versus those that did not, an analysis was conducted in terms of region, winery size, whether wine was made on site, ownership status, and annual turnover. However, none of these factors were statistically significant. 
Table 2. Proportion of respondent wineries that offered cellar door sales.

\begin{tabular}{ccccccccc}
\hline & \# 1997 & $\mathbf{\%} \mathbf{1 9 9 7}$ & $\mathbf{\# ~ 2 0 0 3}$ & $\mathbf{\%} \mathbf{2 0 0 3}$ & $\mathbf{\# ~ 2 0 1 0}$ & $\mathbf{\%} \mathbf{2 0 1 0}$ & $\mathbf{\# 2 0 1 5}$ & $\mathbf{\%} \mathbf{2 0 1 5}$ \\
\hline Offer & 92 & $83 \%$ & 80 & $66.4 \%$ & 70 & $68 \%$ & 53 & $81.5 \%$ \\
Do not offer & 19 & $17 \%$ & 41 & $33.6 \%$ & 33 & $32 \%$ & 12 & $18.5 \%$ \\
Total & 111 & $100 \%$ & 121 & $100 \%$ & 103 & $100 \%$ & 65 & $100 \%$ \\
\hline
\end{tabular}

\subsection{The Importance of Sustainability to Wineries}

Over half of the respondents in the 2015 survey strongly disagreed $(50.8 \%)$ or disagreed $(30.8 \%)$ that sustainability practices were important for the New Zealand wine industry (Figure 1). When compared with the 2010 figures, where the majority of respondents either agreed (33\%) or strongly agreed $(21.4 \%)$, the 2015 figures indicate a strong reversal in the viewpoint taken by the New Zealand wine industry towards the value of sustainable practices for the local industry. However, further questioning revealed a significant split among respondents with respect to the value of sustainable practices. In 2010, over half of the respondents did not believe that sustainability practices provided wineries with a source of competitive advantage. The position had changed in 2015 , with $30.8 \%$ of wineries agreeing that sustainability provided an important source of competitive advantage. However, $24.6 \%$ still disagreed, while $20 \%$ of wineries remained unsure (Figure 2). This shows that opinions amongst New Zealand wine producers are very much divided over the true value of sustainability, despite the emphasis that it is given in international marketing and promotion.

In $2015,78.5 \%$ of the wineries surveyed stated that they were accredited members of the SWNZ; this is an increase from the 2010 survey, in which of $56.3 \%$ of wineries stated that they were accredited members. These figures indicate the seeming disparity between the vision of SWNZ of $100 \%$ industry uptake of the programme (a goal that they originally had hoped to achieve by 2012) and the actual level of adoption. The reality is that some wineries either did not see any true value being gained through accreditation, or they mistrusted the ability of SWNZ to be able to follow through on delivering the strategic intent on which the scheme was based. Nevertheless, when asked about the level of commitment that their winery had toward sustainability, $93.8 \%$ of respondents stated that they had already adopted sustainable practices, while $3.1 \%$ stated that they were planning to adopt sustainable practices, but were not ready yet. The remaining respondents reported that they were not interested in adopting sustainable practices.

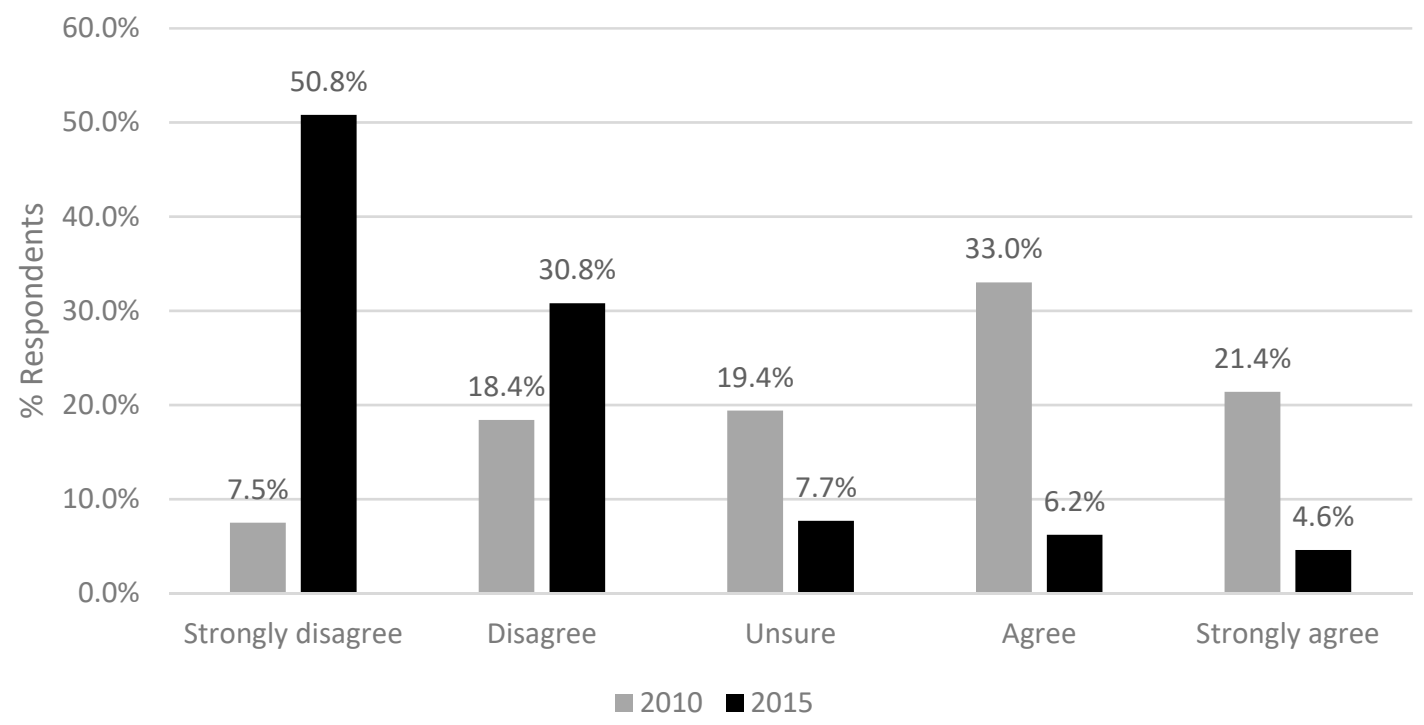

Figure 1. Importance of sustainability practices for the New Zealand wine industry. 


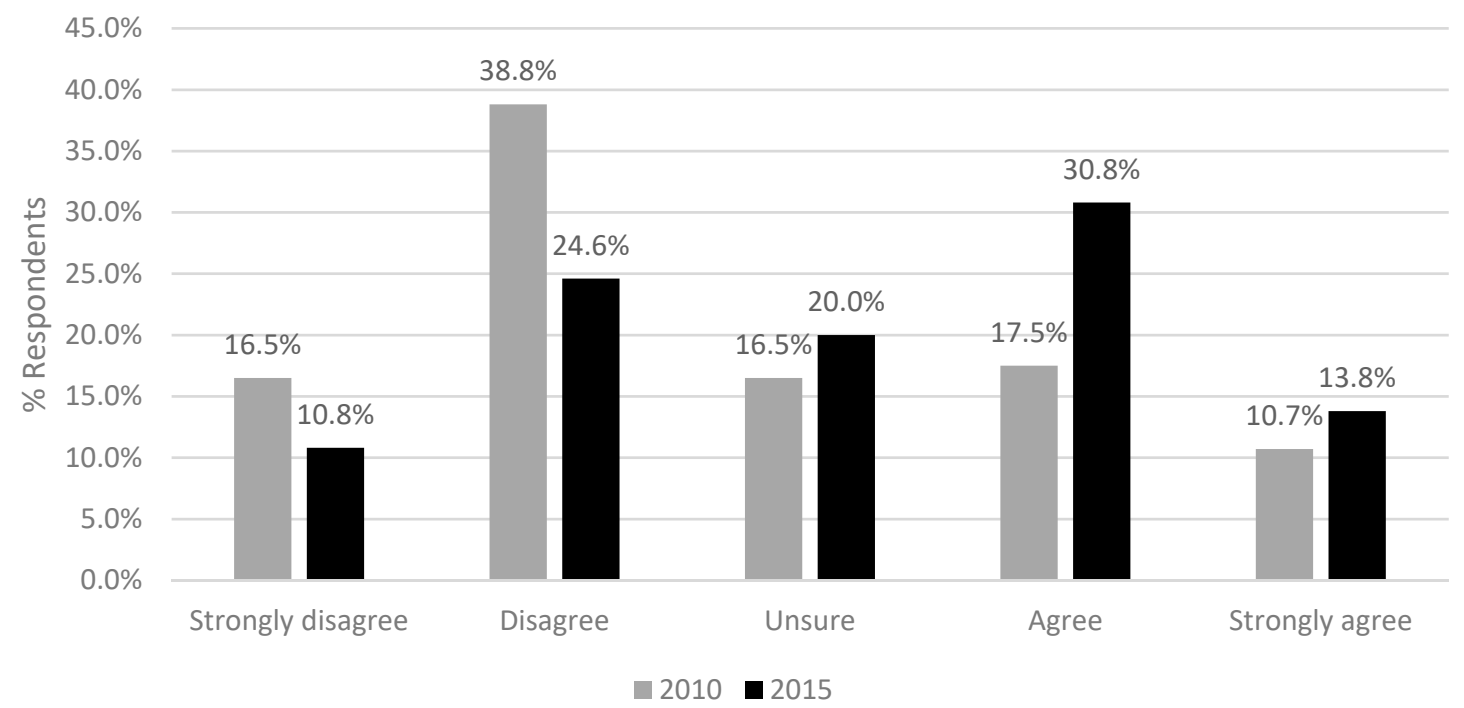

Figure 2. Importance of sustainability practices as a source of competitive advantage.

Impact of Sustainability Issues on Wineries

In order to examine the impact that sustainability issues have had on New Zealand wineries, a series of statements were asked that focused on how winegrowers defined the elements of sustainability. This was assessed via a five-point Likert scale $(1=$ No impact, $5=$ Major impact $)$. The first set of topics that were covered included climate change, corporate social responsibility, business viability, and whether they felt that sustainability incorporated the three elements of climate change: environmental, social, and economic issues. The second set of topics examined whether wineries felt that sustainability meant meeting the needs of the current generation without compromise, or referred to biodiversity, social justice, or other wider environmental issues. A final question asked whether wineries felt that sustainability referred to addressing issues from a long-term perspective (Table 3).

New Zealand wineries were divided over their perceptions of the impact of climate change issues on their organisation and their definitions of sustainability. Nearly half (44.6\%) of wineries stated that climate change had little impact, while $24.6 \%$ responded that they believed that climate change had no impact at all. In contrast, corporate social responsibility and business vitality were seen as more important elements of sustainability. However, wineries were split as to perceptions of the impact of social justice considerations, with $35.4 \%$ of wineries stating that social justice issues had no impact at all, while $27.7 \%$ declared that the same topic had a lot of impact on their winery. Significantly, New Zealand wineries felt that the combination of climate change's environmental, social, and economic issues was important to them, with $60 \%$ stating that this had a major impact on their business. Similarly, $49.2 \%$ of New Zealand wineries viewed other environmental issues outside of those related to climate change as having a major impact on their organisational definition of sustainability. Furthermore, $50.8 \%$ of wineries felt that not compromising on sustainable practices to meet the needs of the current generation had a major impact on how they ran their business. Perhaps unsurprisingly, the same proportion of respondents regarded sustainability as something that addressed issues from a long-term perspective. 
Table 3. How New Zealand wineries define sustainability.

\begin{tabular}{ccccccc}
\hline $\begin{array}{c}\text { How Organisation } \\
\text { Defines Sustainability }\end{array}$ & $\begin{array}{c}\text { No } \\
\text { Impact }\end{array}$ & $\begin{array}{c}\text { Little } \\
\text { Impact }\end{array}$ & $\begin{array}{c}\text { Some } \\
\text { Impact }\end{array}$ & $\begin{array}{c}\text { A Lot of } \\
\text { Impact }\end{array}$ & $\begin{array}{c}\text { Major } \\
\text { Impact }\end{array}$ & Mean \\
\hline Refers to climate change & $24.6 \%$ & $44.6 \%$ & $18.5 \%$ & $9.2 \%$ & $27.7 \%$ & 2.95 \\
\hline $\begin{array}{c}\text { Refers to corporate social } \\
\text { responsibility issues }\end{array}$ & $23.1 \%$ & $10.8 \%$ & $6.2 \%$ & $29.2 \%$ & $30.8 \%$ & 3.34 \\
\hline $\begin{array}{c}\text { Refers to maintaining the } \\
\text { viability of the business }\end{array}$ & $21.5 \%$ & $7.7 \%$ & $15.4 \%$ & $16.9 \%$ & $38.5 \%$ & 3.43 \\
\hline $\begin{array}{c}\text { Incorporates climate change, } \\
\text { environmental, social, and } \\
\text { economic issues }\end{array}$ & $7.7 \%$ & $3.1 \%$ & $10.8 \%$ & $18.5 \%$ & $40.0 \%$ & 4.20 \\
\hline $\begin{array}{c}\text { Refers to meeting the needs of } \\
\text { the current generation } \\
\text { without compromise }\end{array}$ & $15.4 \%$ & $4.6 \%$ & $12.3 \%$ & $16.9 \%$ & $50.8 \%$ & 3.83 \\
\hline $\begin{array}{c}\text { Refers to biodiversity issues } \\
\text { Refers to social justice issues }\end{array}$ & $13.8 \%$ & $10.8 \%$ & $13.8 \%$ & $29.2 \%$ & $32.3 \%$ & 3.55 \\
\hline Refers to environmental issues & $16.9 \%$ & $12.3 \%$ & $13.8 \%$ & $27.7 \%$ & $10.8 \%$ & 2.66 \\
\hline $\begin{array}{c}\text { Refers to addressing issues from } \\
\text { a long-term perspective }\end{array}$ & $20.0 \%$ & $7.7 \%$ & $9.2 \%$ & $12.3 \%$ & $50.8 \%$ & 3.66 \\
\hline
\end{tabular}

Table 4 shows how New Zealand wineries define sustainability based around the same issues covered in Table 3. The key difference here is that Table 4 frames these issues from the perspective of whether survey respondents are accredited SWNZ members or not. The results show significance at the 0.05 level for corporate responsibility issues $(t=1.508$, sig. $=0.031$, and a holistic focus on climate change, environmental, social, and economic issues $(t=1.120$, sig. $=0.006)$. Solely focusing on environmental issues $(t=1.607$, sig. $=0.008)$ was also significant at the 0.05 level.

Table 4. How New Zealand wineries define sustainability based on SWNZ accreditation.

\begin{tabular}{ccc}
\hline How Organisations Define Sustainability & $\boldsymbol{t}$ & sig. \\
\hline Refers to climate change & 0.843 & 0.157 \\
Refers to corporate social responsibility issues & 1.508 & 0.031 \\
Refers to maintaining the viability of the business & 1.351 & 0.416 \\
Incorporates climate change's environmental, social, and economic issues & 1.120 & 0.006 \\
Refers to meeting the needs of the current generation without compromise & 1.147 & 0.130 \\
Refers to biodiversity issues & 1.022 & 0.412 \\
Refers to social justice issues & 0.872 & 0.689 \\
Refers to environmental issues & 1.607 & 0.008 \\
Refers to addressing issues from a long-term perspective & 0.233 & 0.530
\end{tabular}

Significance is measured at the 0.05 level.

Survey participants were asked to respond to a series of statements based on the level of perceived importance that sustainability practices had for particular aspects of their business at their winery. Statements were asked utilising a five-point Likert scale $(1=$ Not at all important, $5=$ Extremely important) (Table 5). Areas in which sustainability was regarded as the most important were a stronger brand, operational efficiency, employee recruitment, and an enhanced ability to enter new markets. Dimensions of the business in which sustainability was regarded as relatively unimportant were migrant worker rights, lowering financial and operating risk, and accessing more potential sources of revenue. Very interestingly, given the supposed significance of sustainability as a factor in tourism, almost one-third of respondents regarded sustainability practices as being unimportant in attracting visitors to their winery. 
Table 5. Importance of sustainability for different aspects of business.

\begin{tabular}{|c|c|c|c|c|c|c|}
\hline Aspect & $\begin{array}{c}\text { Not } \\
\text { Important }\end{array}$ & $\begin{array}{l}\text { Somewhat } \\
\text { Important }\end{array}$ & Important & $\begin{array}{c}\text { Very } \\
\text { Important }\end{array}$ & $\begin{array}{l}\text { Extremely } \\
\text { Important }\end{array}$ & Mean \\
\hline Stronger brand/greater pricing power & $29.2 \%$ & $23.1 \%$ & $16.9 \%$ & $13.8 \%$ & $16.9 \%$ & 2.66 \\
\hline Greater operational efficiency & $23.1 \%$ & $16.9 \%$ & $23.1 \%$ & $24.6 \%$ & $12.3 \%$ & 2.86 \\
\hline Improved customer loyalty & $27.7 \%$ & $12.3 \%$ & $30.8 \%$ & $16.9 \%$ & $12.3 \%$ & 2.74 \\
\hline Enhanced ability to enter new markets & $29.2 \%$ & $7.7 \%$ & $30.8 \%$ & $20.0 \%$ & $12.3 \%$ & 2.78 \\
\hline Migrant workers' rights & $47.7 \%$ & $13.8 \%$ & $26.2 \%$ & $4.6 \%$ & $7.7 \%$ & 2.11 \\
\hline Ability to justify price premium for products & $23.1 \%$ & $18.5 \%$ & $36.9 \%$ & $7.7 \%$ & $13.8 \%$ & 2.71 \\
\hline Attracting visitors to winery & $30.8 \%$ & $16.9 \%$ & $36.9 \%$ & $7.7 \%$ & $7.7 \%$ & 2.44 \\
\hline Lower legal and regulatory risk & $27.7 \%$ & $20.0 \%$ & $23.1 \%$ & $18.5 \%$ & $10.8 \%$ & 2.65 \\
\hline
\end{tabular}

Respondents were also asked to state whether there were potential benefits to employing specific sustainable practices at their winery (utilising a five-point Likert scale $1=$ Not at all important, $5=$ Extremely important) (Table 6). A number of these practices, such as a reduction in the amount of sprays and chemicals used and improved waste management processes, are integral to the SWNZ program. Therefore, it is perhaps unsurprising that reducing the toxicity of harmful chemicals, and reductions in waste production and energy consumption were regarded as being the most beneficial areas in the adoption of sustainable practices, with the reduction of greenhouse gas emissions also being seen as a beneficiary of such measures. However, other, more intangible areas, such as the building of consumer awareness, relationships with suppliers and distributors, and the significance of eco-labelling were not regarding as benefiting as greatly, even though there was a reasonable level of support for their relevance in developing new business opportunities. Table 7 examines the importance of each of the topics examined in Tables 5 and 6, and illustrates that no issues were found to be significant at the 0.05 level.

Table 6. Potential benefits of sustainability practices for New Zealand wineries.

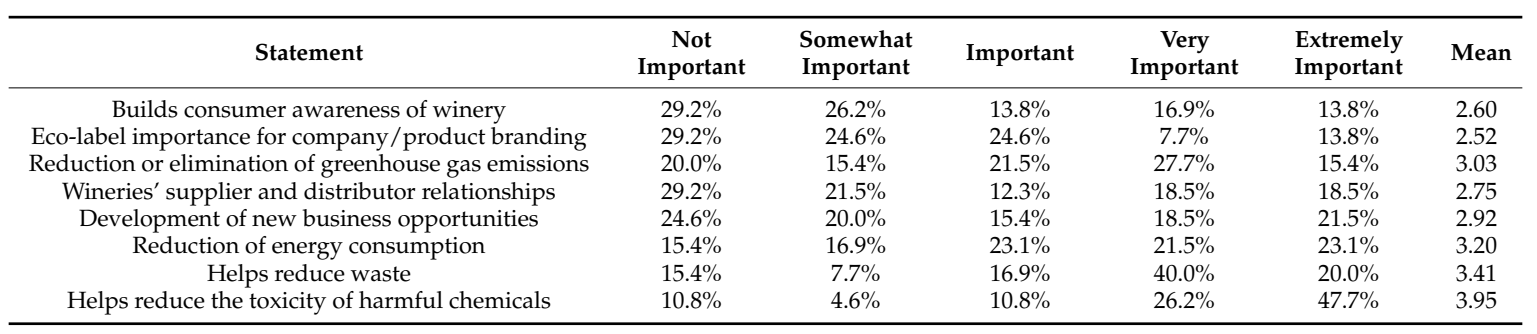

Table 7. Importance of sustainability for different aspects of business based on SWNZ accreditation.

\begin{tabular}{ccc}
\hline Aspect & $t$ & sig. \\
\hline Stronger brand/greater pricing power & 0.464 & 0.590 \\
Employee recruitment, morale, and retention & 0.042 & 0.879 \\
Greater operational efficiency & -0.207 & 0.665 \\
Improved customer loyalty & -0.366 & 0.351 \\
Enhanced ability to enter new markets & 0.429 & 0.551 \\
Migrant workers' rights & 0.119 & 0.342 \\
More potential sources of revenue & 0.441 & 0.131 \\
Lower financial and operating risk & 0.236 & 0.646 \\
Ability to justify price premium for products & 0.861 & 0.674 \\
Attracting visitors to winery & 0.305 & 0.835 \\
Lower legal and regulatory risk & 1.359 & 0.126 \\
Builds consumer awareness of winery & 1.588 & 0.138 \\
Eco-label importance for company/product branding & 1.647 & 0.486 \\
Reduction or elimination of greenhouse gas emissions & 1.429 & 0.779 \\
\hline
\end{tabular}


Table 7. Cont.

\begin{tabular}{ccc}
\hline Aspect & $\boldsymbol{t}$ & sig. \\
\hline Wineries' supplier and distributor relationships & 1.524 & 0.831 \\
Development of new business opportunities & 2.040 & 0.415 \\
Reduction of energy consumption & 1.272 & 0.667 \\
Helps to reduce waste & 1.336 & 0.227 \\
Helps to reduce toxicity of harmful chemicals & 0.080 & 0.264 \\
\hline
\end{tabular}

Significance is measured at the 0.05 level.

\subsection{Why Do Wineries Chose to Employ Sustainable Practices?}

Given that respondents are clearly ambivalent about many aspects of the value of sustainable winegrowing practices, a clear issue is therefore: why adopt them? An overwhelming majority of respondents (89.2\%) stated in the 2015 survey that they did not choose to employ sustainability practices in order to increase revenue, while $70.8 \%$ responded that they did not choose to employ practices in order to reduce costs (Table 8). This trend was consistent with the 2010 survey. The key focus was on the reduction of environmental impacts, which had increased from $60.2 \%$ of respondents in 2010 to $69.2 \%$ in 2015. The reduction of energy consumption was a significant, though lesser concern. Other reasons that respondents gave for the adoption of sustainable practices included: it was the "right thing to do", because it was enforced by New Zealand Winegrowers, so that wineries could legally export, in order to comply with SWNZ requirements, and also because it was mandatory to be a member of SWNZ if wineries wanted to enter wine shows. However, some respondents stated that they felt that SWNZ membership had no real benefit to them, with one noting that they had become BioGro Certified (a New Zealand organic growing accreditation scheme) in order to avoid what they termed a "sustainability whitewash". Another respondent stated: "My winery has been a member of SWNZ for over 15 years. In that time, not one person in the wine trade or anyone who has visited my winery has ever asked about my SWNZ certification. I've reached the conclusion that it has zero value for my winery in terms of a branding tool and attracting visitors." Other responses were also highly critical of the SWNZ programme. One respondent commented, "For smaller wineries, the cost involved coupled with the additional paperwork is just too much to even consider joining the SWNZ programme. We believe that we already practice sustainable methods-we don't need someone to dictate what these are to us". Of interest as well was the statement by one participant: "The compulsory nature of the SWNZ programme is nothing but a disguised tax for wineries. We have to pay it, but the benefits received are negligible, and don't appear to be getting any better. For smaller wineries, it is almost impossible to take part due to the costs involved." The vehemence of many such responses underlines that within the New Zealand wine industry, the adoption of sustainable winegrowing practices is not going as smoothly as portrayed in international marketing and promotional efforts (see [28]).

Table 8. Reasons for winery choosing to employ sustainability practices.

\begin{tabular}{ccccc}
\hline & \multicolumn{2}{c}{$\mathbf{2 0 1 0}$} & \multicolumn{2}{c}{2015} \\
\hline Reason & Yes & No & Yes & No \\
\hline To increase revenue & $11.7 \%$ & $88.3 \%$ & $10.8 \%$ & $89.2 \%$ \\
To reduce costs & $29.1 \%$ & $70.9 \%$ & $29.2 \%$ & $70.8 \%$ \\
To increase market share & $16.5 \%$ & $83.5 \%$ & $15.4 \%$ & $84.6 \%$ \\
To reduce energy consumption & $32 \%$ & $68 \%$ & $33.8 \%$ & $66.2 \%$ \\
To reduce environmental impact & $60.2 \%$ & $39.8 \%$ & $69.2 \%$ & $30.8 \%$ \\
To establish/or exploit new market opportunities & $19.4 \%$ & $80.6 \%$ & $13.8 \%$ & $86.2 \%$ \\
To improve productivity & $21.4 \%$ & $78.6 \%$ & $13.8 \%$ & $86.2 \%$ \\
To attract visitors to my winery & $12.6 \%$ & $87.4 \%$ & $15.4 \%$ & $84.6 \%$ \\
Other & $29.1 \%$ & $70.9 \%$ & $26.2 \%$ & $73.8 \%$ \\
\hline
\end{tabular}


Table 9 compares the significance of the reasons given in 2010 and 2015 for employing sustainable practices amongst New Zealand wineries based on SWNZ accreditation. Of interest here is that in 2010, increasing revenue $(t=-1.452$, sig. $=0.004)$, increasing market share $(t=-1.338$, sig. $=0.008)$, and reducing energy consumption $(t=-3.420$, sig. $=0.000)$ were all significant at the 0.05 level. Establishing and/or exploiting new market opportunities $(t=-1.970$, sig. $=0.000)$ and using sustainable practices to attract winery visitors $(t=-1.690$, sig. $=0.001)$ were also found to be significant in 2010 as well. Examination of these same issues in the 2015 survey showed that only attracting winery visitors $(t=-1.174$, sig. $=0.037)$ was significant at the 0.05 level. This indicates that in the five years between these two surveys, New Zealand wineries appear to have become more negative towards the benefits derived from sustainable practices, yet many still see such practices as having some form of value in attracting wine tourists.

Table 9. Reasons for winery choosing to employ sustainability practices based on SWNZ accreditation.

\begin{tabular}{ccccc}
\hline & \multicolumn{2}{c}{$\mathbf{2 0 1 0}$} & \multicolumn{2}{c}{$\mathbf{2 0 1 5}$} \\
\hline Reason & $\boldsymbol{t}$ & $\mathbf{s i g}$ & $\boldsymbol{t}$ & $\mathbf{s i g}$. \\
\hline To increase revenue & -1.452 & 0.004 & -0.487 & 0.314 \\
To reduce costs & 0.387 & 0.446 & -0.060 & 0.903 \\
To increase market share & -1.338 & 0.008 & -0.127 & 0.799 \\
To reduce energy consumption & -3.420 & 0.000 & 0.164 & 0.754 \\
To reduce environmental impact & -1.651 & 0.017 & 0.198 & 0.681 \\
To establish/or exploit new market opportunities & -1.970 & 0.000 & -0.811 & 0.082 \\
To improve productivity & 0.186 & 0.711 & 0.053 & 0.916 \\
To attract visitors to my winery & -1.690 & 0.001 & -1.174 & 0.037 \\
Other & -2.334 & 0.000 & -0.163 & 0.740 \\
\hline
\end{tabular}

Significance is measured at the 0.05 level.

\subsection{Biosecurity and Wine Tourism}

When winegrowers were asked whether they had biosecurity measures in place for wine tourists in 2015 (Table 10), 30.8\% of participants believed that the current measures that they employed were adequate, which is an $8.5 \%$ increase from the 2010 figure, and an advance on the 2003 survey, which showed that only $11.9 \%$ of wineries had biosecurity measures in place. These figures highlight that there is a significant gap in the actions taken by wineries and the potential biosecurity threats they face from winery visitation, which poses a risk because visitors may be vectors for disease or an exotic species [8,9]. Nearly half of the New Zealand wineries surveyed report that visitors are able to wander freely among their vines. This attitude towards risk mitigation suggests that a more cautious approach that is underpinned by a higher level of awareness with regard to the consequences that a disease outbreak could have for the New Zealand wine industry is required. In 2015, just under half of the wineries surveyed (43.1\%) indicated that they were unsure of whether the current level of information available regarding biosecurity threats that they received was adequate, which was a figure similar to that of the previous survey (Figure 3). Nevertheless, $55.4 \%$ of wineries surveyed in 2015 believed that there was no need for a biosecurity component within the SWNZ scheme, which could be a potential avenue to better communicate biosecurity management to winegrowers, especially given that one of the key objectives of the New Zealand Winegrowers biosecurity strategy is ensuring that "members' awareness of biosecurity risks and mitigations is maximised" [28] (p. 21). Without protection from disease or invasive species, any long-term strategies that wineries have in place with regard to sustainability initiatives will be threatened [56]. 
Table 10. Biosecurity measures and visitor access.

\begin{tabular}{ccccccc}
\hline & \multicolumn{2}{c}{$\mathbf{2 0 0 3}$} & \multicolumn{2}{c}{$\mathbf{2 0 1 0}$} & \multicolumn{2}{c}{$\mathbf{2 0 1 5}$} \\
\hline Statement & Yes & No & Yes & No & Yes & No \\
\hline Vineyard has biosecurity measures in place for tourists & $11.9 \%$ & $89.1 \%$ & $22.3 \%$ & $77.7 \%$ & $30.8 \%$ & $69.2 \%$ \\
Visitors can wander freely amongst vines at winery & N/A & N/A & $31.1 \%$ & $68.9 \%$ & $44.6 \%$ & $55.4 \%$ \\
\hline
\end{tabular}

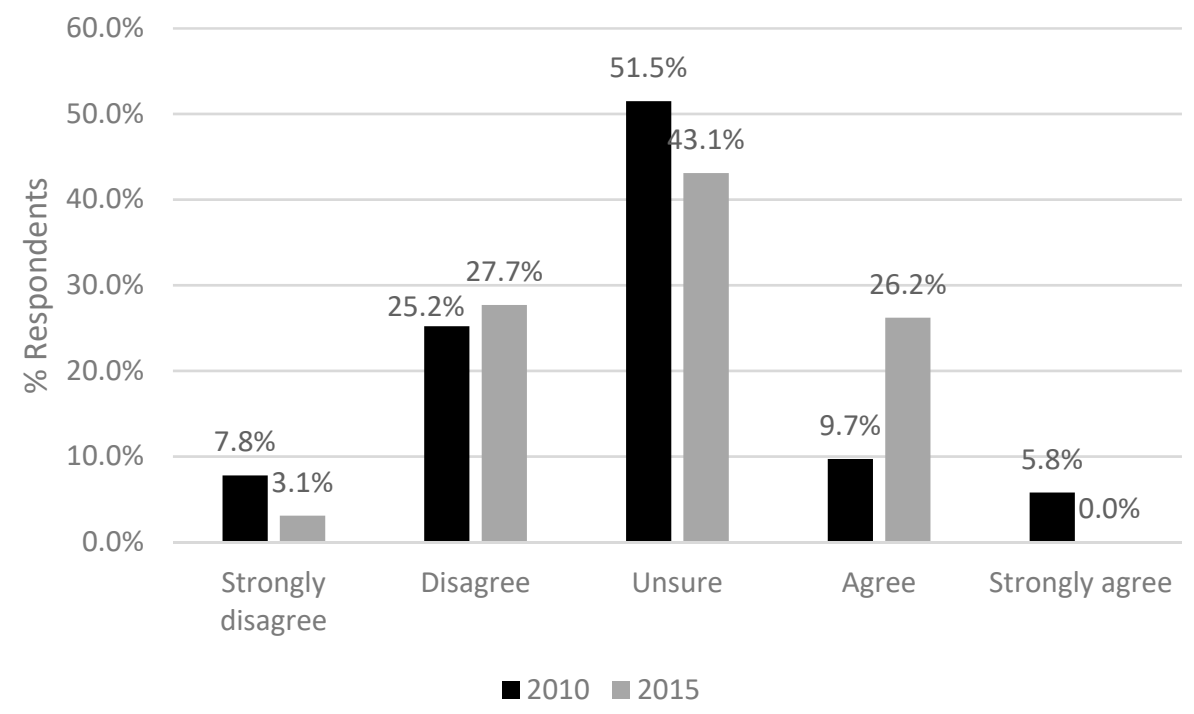

Figure 3. Winery receives adequate biosecurity information from government agencies.

\section{Discussion}

The New Zealand wine industry is of considerable importance to regional economies as a result of its contribution to wine production and wine tourism $[7,27]$. Sustainability and the qualities of a natural environment are an important part of the brand positioning for New Zealand wine and tourism $[11,29,30]$. However, the results of the research discussed in this paper indicate that there are substantial gaps with respect to the brand attributes that are communicated, and what is actually implemented at the firm level. Furthermore, although wine tourism is an important component of winegrowers' business strategies, as it provides opportunities for both immediate (cellar door) and long-term (retail) sales [1], there is a disconnect between winery sustainability practices and the involvement of winegrowers in tourism. Such a result reinforces previous research that found that the innovative practices of New Zealand winegrowers who are engaged with cellar door sales are related to marketing - which itself appears related to the attraction of the wine tourist market segment-rather than sustainability [111]. Winery sustainability practices are instead being driven by a top-down approach by the export-focussed national body, rather than tourism, or even what wineries themselves may want to focus on with respect to sustainability. Yet, as survey results and comments from respondents demonstrate, there is often substantial divergence between the interests and perspectives of winegrowers and national level initiatives. In some cases, this may lead to the substantial resentment of such initiatives, especially if the sustainability practices that winegrowers have to adopt to be part of SWNZ are not seen as providing an economic return. For some New Zealand wineries, the mandatory nature of this programme and the cost involved to be a member appears to be prohibitive. This effect appears to result in a group of wineries that regard themselves as penalised in terms of export potential purely by the inflexibility of the sustainability indicators of the SWNZ, rather than their preferred strategies. The mandatory nature of the programme for exporters also reinforces the impression that it has been developed as much to reinforce the brand positioning of New Zealand wine, rather than any commitment to actually be "sustainable", especially given that the programme is 
focused on select environmental indicators, and ignores some of the social and labour dimensions of sustainability that are a hallmark of many United States wine sustainability programs [1].

The New Zealand wine industry also appears to have significant gaps in knowledge-sharing within the context of sustainability and biosecurity. Although the industry explicitly supports biosecurity strategies at the national border level [28], there is much more limited attention to biosecurity at the winery scale. This is potentially a major management issue for wine tourism and tourism in rural areas, given the potential risks that visitors represent to vineyards [8,9]. Given the importance of these environmental aspects to wine tourism and other forms of food tourism in rural regions, research on tourism and biosecurity remains an area that requires urgent further research.

It is possible that the adoption of sustainability practices, as with the significance of wine tourism in business practices, may be a function of the stage that each winery is at in its life course, and/or the extent to which they are family-owned firms. However, there appeared to be no firm statistical support for that observation in the present study. Furthermore, although larger New Zealand winegrowers appear more innovative than smaller ones [111], there is no evidence to suggest that they are inherently more committed to sustainability. Indeed, although further confirmation is necessary, it is highly likely that commitment to SWNZ is associated with it being a requirement for export-marketing support; therefore, this raises significant future research questions with respect to the role of regulatory and institutional structures in influencing the adoption of sustainable businesses practices.

The study also raises some fundamental issues about the sustainability practices of rural tourism businesses and their comparability, and poses significant questions as to what actually constitutes a tourism business, given that tourism does not have a standard industry classification. For example, the business models and innovation profiles of many rural firms are considerably different from those of the wineries that are engaged in wine tourism, with wineries far more focussed on sustainability and reducing energy consumption [111] than businesses in the New Zealand accommodation and restaurant sector [112], or even other tourism attractions. Therefore, understandings of rural tourism business sustainability practices potentially need to be grounded in awareness of broader sectoral demands on firms and constraints with respect to business strategies, rather than just "tourism" [99]. In particular, and as in the specific case of winegrowers, the partially-industrialised nature of tourism activities means that only a proportion of a business' customer base or income is derived from tourism, and as a result, any analysis of sustainability practices or other aspects of firm strategy and management require separating out the role of tourism in business decision-making as well as the relative mix between tourism and non-tourism influences in strategy setting [111]. Critically, the sustainability practices of New Zealand wineries and the national programme to which they often have to belong is geared towards practices within a specific site. Similar to many assessments of the sustainability of a firm or location, these practices also fail to adequately account for the impacts of visitor mobility on the footprint of the business, whether this be in the form of the biosecurity risks posed to winegrowers by tourists, the environmental costs of transporting wine to international consumers, or how researchers conceptualise tourism firms in rural or other areas.

Author Contributions: C.M.H. and T.B. conceived and designed the survey; T.B. performed the 2010 and 2015 surveys; T.B. analysed the data; C.M.H. and P.C. contributed advice with analysis; T.B. and C.M.H. wrote the paper.

Conflicts of Interest: The authors declare no conflict of interest.

\section{References}

1. Hall, C.M.; Mitchell, R. Wine Marketing: A Practical Guide; Butterworth-Heinemann: Oxford, UK, 2008; ISBN-13 978-0-7506-5420-3.

2. Grimstad, S. Developing a framework for examining business-driven sustainability initiatives with relevance to wine tourism clusters. Int. J. Wine Bus. Res. 2011, 23, 62-82. [CrossRef]

3. Carmichael, B.A.; Senese, D.M. Competitiveness and sustainability in wine tourism regions: The application of a stage model of destination development to two Canadian wine regions. In The Geography of Wine; Dougherty, P.H., Ed.; Springer: Dordrecht, The Netherlands, 2012; pp. 159-178. ISBN 978-94-007-0463-3. 
4. Hall, C.M.; Gössling, S. (Eds.) Sustainable Culinary Systems: Local Foods, Innovation, and Tourism E Hospitality; Routledge: Abingdon, UK, 2013; ISBN 978-1-138-91292-2.

5. Hall, C.M.; Gössling, S. (Eds.) Food Tourism and Regional Development: Networks, Products and Trajectories; Routledge: Abingdon, UK, 2016; ISBN 978-0-415-53370-6.

6. Kennedy, C. The Greenest Grape: New Zealand's Commitment to Sustainable Winegrowing. 2009. Available online: http:/ / lehigh.edu/ incntr/publications/documents /GreeGrape.pdf (accessed on 31 January 2018).

7. Hall, C.M.; Gössling, S. From food tourism and regional development to food, tourism and regional development: Themes and issues in contemporary foodscapes. In Food Tourism and Regional Development: Networks, Products and Trajectories; Hall, C.M., Gössling, S., Eds.; Routledge: Abingdon, UK, 2016; pp. 3-57. ISBN 978-0-415-53370-6.

8. Hall, C.M. Biosecurity and wine tourism: Is a vineyard a farm? J. Wine Res. 2003, 14, 121-126. [CrossRef]

9. Hall, C.M. Biosecurity and wine tourism. Tour. Manag. 2005, 26, 931-938. [CrossRef]

10. Hall, C.M. Wine tourism in New Zealand. In Tourism Down Under, Tourism Research Conference; Kearsley, G., Ed.; Centre for Tourism, University of Otago: Dunedin, New Zealand, 1996; pp. 109-119.

11. Gabzdylova, B.; Raffensperger, J.; Castka, P. Sustainability in the New Zealand wine industry: Drivers, stakeholders and practices. J. Clean. Prod. 2009, 17, 992-998. [CrossRef]

12. Dodds, R.; Graci, S.; Ko, S.; Walker, L. What drives environmental sustainability in the New Zealand wine industry? An examination of driving factors and practices. Int. J. Wine Bus. Res. 2013, 25, 164-184. [CrossRef]

13. Hall, C.M.; Johnson, G. Wine tourism in New Zealand: Larger bottles or better relationships. In Trails in the Third Millenium, Conference Proceedings; Higham, J., Kearsley, G., Eds.; Centre for Tourism, University of Otago: Dunedin, New Zealand, 1997; pp. 73-86.

14. Flint, D.J.; Golicic, S.L. Searching for competitive advantage through sustainability: A qualitative study in the New Zealand wine industry. Int. J. Phys. Distrib. Logist. Manag. 2009, 39, 841-860. [CrossRef]

15. Alant, K.; Bruwer, J. Wine tourism behaviour in the context of a motivational framework for wine regions and cellar doors. J. Wine Res. 2004, 15, 27-37. [CrossRef]

16. Alonso, A.D.; Bressan, A.; O'Shea, M.; Krajsic, V. Perceived benefits and challenges to wine tourism involvement: An international perspective. Int. J. Tour. Res. 2015, 17, 66-81. [CrossRef]

17. Mitchell, R.; Hall, C.M. Wine tourism research: The state of play. Tour. Rev. Int. 2006, 9, 307-332. [CrossRef]

18. Hall, C.M.; Cambourne, B.; Macionis, N.; Johnson, G. Wine tourism and network development in Australia and New Zealand: Review, establishment and prospects. Int. J. Wine Mark. 1997, 9, 5-31. [CrossRef]

19. Mitchell, R.; Hall, C.M. The post-visit consumer behaviour of New Zealand winery visitors. J. Wine Res. 2004, 15, 39-49. [CrossRef]

20. Batra, A. An exploratory study on specific preferences and characteristics of wine tourists. Anatolia Int. J. Tour. Hosp. Res. 2008, 19, 271-286. [CrossRef]

21. Charters, S.; O'Neill, M. Service quality at the cellar door: A comparison between regions. Int. J. Wine Mark. 2001, 13, 7-17. [CrossRef]

22. Alonso, A.D.; Northcote, J. Small winegrowers' views on their relationship with local communities. J. Wine Res. 2008, 19, 143-158. [CrossRef]

23. Stavrinoudis, T.A.; Tsartas, P.; Chatzidakis, G. Study of the major supply factors and business choices affecting the growth rate of wine tourism in Greece. Curr. Issues Tour. 2012, 15, 627-647. [CrossRef]

24. Popp, L.; McCole, D. Understanding tourists' itineraries in emerging rural tourism regions: The application of paper-based itinerary mapping methodology to a wine tourism region in Michigan. Curr. Issues Tour. 2016, 19, 988-1004. [CrossRef]

25. Hall, C.M. Boosting food and tourism-related regional economic development. In Food and the Tourism Experience: The OECD-Korea Workshop; OECD Studies on Tourism; OECD Publishing: Paris, France, 2012; pp. 49-62.

26. Tourism New Zealand. Tourist Special Interest. Wine Tourism; Tourism Profile; New Zealand February 2014; Tourism New Zealand: Auckland, New Zealand, 2014.

27. Baird, T.; Hall, C.M. Between the vines: Wine tourism in New Zealand. In Social, Cultural and Economic Impacts of Wine in New Zealand; Howland, P., Ed.; Routledge: Abingdon, UK, 2014; pp. 191-207, ISBN 978-0-415-63979-8.

28. New Zealand Winegrowers. Annual Report 2016; New Zealand Winegrowers: Auckland, New Zealand, 2016. 
29. Hall, C.M.; Baird, T. Brand New Zealand wine: Architecture, positioning and vulnerability in the global marketplace. In Social, Cultural and Economic Impacts of Wine in New Zealand; Howland, P., Ed.; Routledge: Abingdon, UK, 2014; pp. 105-119. ISBN 978-0-415-63979-8.

30. Hall, C.M. Tourism destination branding and its effects on national branding strategies: Brand New Zealand, clean and green but is it smart? Eur. J. Tour. Hosp. Recreat. 2010, 1, 68-89.

31. Ohmart, C. Green wine without green washing? Wines Vines 2008, 89, 77-79.

32. Alonso, A.D.; Liu, Y. Old wine region, new concept and sustainable development: Winery entrepreneurs' perceived benefits from wine tourism on Spain's Canary Islands. J. Sustain. Tour. 2012, 20, 991-1009. [CrossRef]

33. Flores, S.S. What is sustainability in the wine world? A cross-country analysis of wine sustainability frameworks. J. Clean. Prod. 2018, 172, 2301-2312. [CrossRef]

34. Forbes, S.L.; Cohen, D.A.; Cullen, R.; Wratten, S.D.; Fountain, J. Consumer attitudes regarding environmentally sustainable wine: An exploratory study of the New Zealand marketplace. J. Clean. Prod. 2009, 17, 1195-1199. [CrossRef]

35. Herath, I.; Green, S.; Horne, D.; Singh, R.; McLaren, S.; Clothier, B. Water footprinting of agricultural products: Evaluation of different protocols using a case study of New Zealand wine. J. Clean. Prod. 2013, 44, 159-167. [CrossRef]

36. Jones, M.F.; Singh, N.; Hsiung, Y. Determining the critical success factors of the wine tourism region of Napa from a supply perspective. Int. J. Tour. Res. 2015, 17, 261-271. [CrossRef]

37. Klohr, B.; Fleuchaus, R.; Theuvsen, L. Sustainability: Implementation programs and communication in the leading wine producing countries. In Proceedings of the 7th International Conference of the Academy of Wine Business Research (AWBR), St. Catharines, ON, Canada, 12-15 June 2013.

38. Montella, M.M. Wine tourism and sustainability: A review. Sustainability 2017, 9, 113. [CrossRef]

39. Pomarici, E.; Vecchio, R.; Verneau, F. A future of sustainable wine? A reasoned review and discussion of ongoing programs around the world. Calitatea 2014, 15, 123-128.

40. Signori, P.; Flint, D.J.; Golicic, S.L. Constrained innovation on sustainability in the global wine industry. J. Wine Res. 2017, 28, 71-90. [CrossRef]

41. Spielmann, N. Larger and better: Examining how winery size and foreign investments interact with sustainability attitudes and practices. Int. J. Wine Bus. Res. 2017, 29, 178-194. [CrossRef]

42. Warner, K.D. The quality of sustainability: Agroecological partnerships and the geographic branding of California winegrapes. J. Rural Stud. 2007, 23, 142-155. [CrossRef]

43. Marshall, R.S.; Akoorie, M.E.M.; Hamann, R.; Sinha, P. Environmental practices in the wine industry: An empirical application of the theory of reasoned action and stakeholder theory in the United States and New Zealand. J. World Bus. 2010, 45, 405-414. [CrossRef]

44. Nowak, L.I.; Washburn, J.H. Building brand equity: Consumer reactions to proactive environmental policies by the winery. Int. J. Wine Mark. 2002, 14, 5-19. [CrossRef]

45. Barber, N.; Taylor, C.; Strick, S. Wine consumers' environmental knowledge and attitudes: Influence on willingness to purchase. Int. J. Wine Res. 2009, 1, 59-72. [CrossRef]

46. Annunziata, E.; Pucci, T.; Frey, M.; Zanni, L. The role of organizational capabilities in attaining corporate sustainability practices and economic performance: Evidence from Italian wine industry. J. Clean. Prod. 2018, 171, 1300-1311. [CrossRef]

47. Atkin, T.; Gilinsky Jr, A.; Newton, S.K. Environmental strategy: Does it lead to competitive advantage in the US wine industry? Int. J. Wine Bus. Res. 2012, 24, 115-133. [CrossRef]

48. Gilinsky, A., Jr.; Newton, S.K.; Atkin, T.S.; Santini, C.; Cavicchi, A.; Casas, A.R.; Huertas, R. Perceived efficacy of sustainability strategies in the US, Italian, and Spanish wine industries: A comparative study. Int. J. Wine Bus. Res. 2015, 27, 164-181. [CrossRef]

49. Golicic, S.L.; Flint, D.J.; Signori, P. Building business sustainability through resilience in the wine industry. Int. J. Wine Bus. Res. 2017, 29, 74-97. [CrossRef]

50. Zucca, G.; Smith, D.E.; Mitry, D.J. Sustainable viticulture and winery practices in California: What is it, and do customers care. Int. J. Wine Bus. Res. 2009, 2, 189-194.

51. Shaw, L.; Lubell, M.; Ohmart, C. The evolution of local partnerships for sustainable agriculture. Soc. Nat. Resour. 2011, 24, 1078-1095. [CrossRef] 
52. Alonso, A.D. How 'green' are small wineries? Western Australia's case. Br. Food J. 2010, 112, $155-170$. [CrossRef]

53. Wynberg, R. A decade of biodiversity conservation and use in South Africa: Tracking progress from the Rio Earth Summit to the Johannesburg World Summit on Sustainable Development. S. Afr. J. Sci. 2002, 98, 233-243.

54. Harrus, S.; Baneth, G. Drivers for the emergence and re-emergence of vector-borne protozoal and bacterial diseases. Int. J. Parasitol. 2005, 35, 1309-1318. [CrossRef] [PubMed]

55. Wilkins, M.; Hall, C.M. An industry stakeholder SWOT analysis of wine tourism in the Okanagan Valley, British Columbia. Int. J. Wine Mark. 2001, 13, 77-81. [CrossRef]

56. Poitras, L.; Getz, D. Sustainable wine tourism: The host community perspective. J. Sustain. Tour. 2006, 14, 425-448. [CrossRef]

57. Christ, K.L.; Burritt, R.L. Critical environmental concerns in wine production: An integrative review. J. Clean. Prod. 2013, 53, 232-242. [CrossRef]

58. Knowles, L.; Hill, R. Environmental initiatives in South African wineries: A comparison between small and large wineries. Corp. Soc. Responsib. Environ. Manag. 2001, 8, 210-228. [CrossRef]

59. Pullman, M.E.; Maloni, M.J.; Dillard, J. Sustainability practices in food supply chains: How is wine different? J. Wine Res. 2010, 21, 35-56. [CrossRef]

60. Ene, S.A.; Teodosiu, C.; Robu, B.; Volf, I. Water footprint assessment in the winemaking industry: A case study for a Romanian medium size production plant. J. Clean. Prod. 2013, 43, 122-135. [CrossRef]

61. Sheridan, C.M.; Bauer, F.F.; Burton, S.; Lorenzen, L. A critical process analysis of wine production to improve cost, quality and environmental performance. Water Sci. Technol. 2005, 51, 39-46. [PubMed]

62. Kumar, A.; Frost, P.; Correll, R.; Oemcke, D. Winery Wastewater Generation, Treatment and Disposal: A Survey of Australian Practice; CSIRO: Glen Osmond, SA, Australia, 2009.

63. Chaves, M.M.; Santos, T.P.; de Souza, C.R.; Ortuño, M.F.; Rodrigues, M.I.; Lopes, C.M.; Maroco, J.P.; Pereira, J.S. Deficit irrigation in grapevine improves water-use efficiency while controlling vigour and production quality. Ann. Appl. Biol. 2007, 150, 237-252. [CrossRef]

64. Keller, M. Managing grapevines to optimise fruit development in a challenging environment: A climate change primer for viticulturists. Aust. J. Grape Wine Res. 2010, 16, 56-69. [CrossRef]

65. Hughey, K.F.D.; Tait, S.V.; O'Connell, M.J. Qualitative evaluation of three 'environmental management systems' in the New Zealand wine industry. J. Clean. Prod. 2005, 13, 1175-1187. [CrossRef]

66. Walsdorff, A.; Van Kraayenburg, M.; Barnardt, C.A. A multi-site approach towards integrating environmental management in the wine production industry. Water Sci. Technol. 2005, 51, 61-69. [CrossRef] [PubMed]

67. Tee, E.; Boland, A.-M.; Medhurst, A. Voluntary adoption of Environmental Management Systems in the Australian wine and grape industry depends on understanding stakeholder objectives and drivers. Aust. J. Exp. Agric. 2007, 47, 273-283. [CrossRef]

68. Musee, N.; Lorenzen, L.; Aldrich, C. Cellar waste minimization in the wine industry: A systems approach. J. Clean. Prod. 2007, 15, 417-431. [CrossRef]

69. Ruggieri, L.; Cadena, E.; Martínez-Blanco, J.; Gasol, C.M.; Rieradevall, J.; Gabarrell, X.; Gea, T.; Sort, X.; Sánchez, A. Recovery of organic wastes in the Spanish wine industry. Technical, economic and environmental analyses of the composting process. J. Clean. Prod. 2009, 17, 830-838. [CrossRef]

70. Bustamante, M.A.; Moral, R.; Paredes, C.; Pérez-Espinosa, A.; Moreno-Caselles, J.; Pérez-Murcia, M.D. Agrochemical characterisation of the solid by-products and residues from the winery and distillery industry. Waste Manag. 2008, 28, 372-380. [CrossRef] [PubMed]

71. Devesa-Rey, R.; Vecino, X.; Varela-Alende, J.L.; Barral, M.T.; Cruz, J.M.; Moldes, A.B. Valorization of winery waste vs. the costs of not recycling. Waste Manag. 2011, 31, 2327-2335. [CrossRef] [PubMed]

72. Sogari, G.; Pucci, T.; Aquilani, B.; Zanni, L. Millennial generation and environmental sustainability: The role of social media in the consumer purchasing behavior for wine. Sustainability 2017, 9, 1911. [CrossRef]

73. Forbes, S.L.; De Silva, T.-A. Analysis of environmental management systems in New Zealand wineries. Int. J. Wine Bus. Res. 2012, 24, 98-114. [CrossRef]

74. Barber, N.; Taylor, D.C.; Deale, C.S. Wine tourism, environmental concerns, and purchase intention. J. Travel Tour. Mark. 2010, 27, 146-165. [CrossRef]

75. Cichelli, A.; Pattara, C.; Petrella, A. Sustainability in mountain viticulture. The case of the Valle Peligna. Agric. Agric. Sci. Procedia 2016, 8, 65-72. [CrossRef] 
76. Navarro, A.; Puig, R.; Kılıç, E.; Penavayre, S.; Fullana-i-Palmer, P. Eco-innovation and benchmarking of carbon footprint data for vineyards and wineries in Spain and France. J. Clean. Prod. 2017, 142, 1661-1671. [CrossRef]

77. Navarro, A.; Puig, R.; Fullana-i-Palmer, P. Product vs corporate carbon footprint: Some methodological issues. A case study and review on the wine sector. Sci. Total Environ. 2017, 581, 722-733. [CrossRef] [PubMed]

78. Steenwerth, K.L.; Strong, E.B.; Greenhut, R.F.; Williams, L.; Kendall, A. Life cycle greenhouse gas, energy, and water assessment of wine grape production in California. Int. J. Life Cycle Assess. 2015, 20, 1243-1253. [CrossRef]

79. Varsei, M.; Christ, K.; Burritt, R. Bottling location and the global wine supply chain: Dollar, water and carbon trade-offs. In Academy of Management Proceedings 2015; Academy of Management: Briarcliff Manor, NY, USA, 2015; pp. 12112-12120. [CrossRef]

80. Webb, L.B.; Whetton, P.H.; Barlow, E.W.R. Climate change and winegrape quality in Australia. Clim. Res. 2008, 36, 99-111. [CrossRef]

81. Colman, T.; Päster, P. Red, white, and 'green': The cost of greenhouse gas emissions in the global wine trade. J. Wine Res. 2009, 20, 15-26. [CrossRef]

82. Reich-Weiser, C.; Paster, P.; Erickson, C.; Dornfeld, D. The role of transportation on the GHG emissions of wine. J. Wine Res. 2010, 21, 197-206. [CrossRef]

83. Forsyth, K.; Oemcke, D.; Michael, P. Greenhouse Gas Accounting Protocol for the International Wine Industry; Provisor Pty Ltd.: Glen Osmond, Australia, 2008.

84. Jones, G.V.; White, M.A.; Cooper, O.R.; Storchmann, K. Climate change and global wine quality. Clim. Chang. 2005, 73, 319-343. [CrossRef]

85. Galbreath, J. To what extent is business responding to climate change? Evidence from a global wine producer. J. Bus. Ethics 2011, 104, 421-432. [CrossRef]

86. Galbreath, J.; Charles, D.; Oczkowski, E. The drivers of climate change innovations: Evidence from the Australian wine industry. J. Bus. Ethics 2016, 135, 217-231. [CrossRef]

87. Ashenfelter, O.; Storchmann, K. Climate change and wine: A review of the economic implications. J. Wine Econ. 2016, 11, 105-138. [CrossRef]

88. Jones, G.V.; Goodrich, G.B. Influence of climate variability on wine regions in the western USA and on wine quality in the Napa Valley. Clim. Res. 2008, 35, 241-254. [CrossRef]

89. Mozell, M.R.; Thach, E. The impact of climate change on the global wine industry: Challenges \& solutions. Wine Econ. Policy 2014, 3, 81-89. [CrossRef]

90. Ollat, N.; Van Leeuwen, C.; de Cortazar-Atauri, I.G.; Touzard, J.-M. The challenging issue of climate change for sustainable grape and wine production. Int. J. Vine Wine Sci. 2017, 51, 59-60. [CrossRef]

91. Schultz, H.R. Global climate change, sustainability, and some challenges for grape and wine production. J. Wine Econ. 2016, 11, 181-200. [CrossRef]

92. Drappier, J.; Thibon, C.; Rabot, A.; Geny-Denis, L. Relationship between wine composition and temperature: Impact on Bordeaux wine typicity in the context of global warming. Crit. Rev. Food Sci. Nutr. 2017. [CrossRef] [PubMed]

93. Nicholas, K.A.; Durham, W.H. Farm-scale adaptation and vulnerability to environmental stresses: Insights from winegrowing in Northern California. Glob. Environ. Chang. 2012, 22, 483-494. [CrossRef]

94. Nemani, R.R.; White, M.A.; Cayan, D.R.; Jones, G.V.; Running, S.W.; Coughlan, J.C. Asymmetric climatic warming improves California vintages. Climat. Res. 2001, 19, 25-34. [CrossRef]

95. Cyr, D.; Kusy, M.; Shaw, A.B. Climate change and the potential use of weather derivatives to hedge vineyard harvest rainfall risk in the Niagara region. J. Wine Res. 2010, 21, 207-227. [CrossRef]

96. Battaglini, A.; Barbeau, G.; Bindi, M.; Badeck, F.-W. European winegrowers' perceptions of climate change impact and options for adaptation. Reg. Environ. Chang. 2009, 9, 61-73. [CrossRef]

97. Diffenbaugh, N.S.; White, M.A.; Jones, G.V.; Ashfaq, M. Climate adaptation wedges: A case study of premium wine in the western United States. Environ. Res. Lett. 2011, 6, 024024. [CrossRef]

98. Pickering, K.; Plummer, R.; Shaw, T.; Pickering, G. Assessing the adaptive capacity of the Ontario wine industry for climate change adaptation. Int. J. Wine Res. 2015, 6, 13-27. [CrossRef]

99. Hall, C.M.; Prayag, G.; Amore, A. Tourism and Resilience: Individual, Organisational and Destination Perspectives; Channelview Press: Bristol, UK, 2018; ISBN 9781845416300. 
100. Vink, N.; Deloire, A.; Bonnardot, V.; Ewert, J. Climate change and the future of South Africa's wine industry. Int. J. Clim. Chang. Strateg. Manag. 2012, 4, 420-441. [CrossRef]

101. Berghoef, N.; Dodds, R. Determinants of interest in eco-labeling in the Ontario wine industry. J. Clean. Prod. 2013, 52, 263-271. [CrossRef]

102. Delmas, M.A.; Grant, L.E. Eco-labeling strategies and price-premium: The wine industry puzzle. Bus. Soc. 2014, 53, 6-44. [CrossRef]

103. Jones, G.V. Sustainable Vineyard Developments Worldwide. 2012. Available online: https:/ / www.linfield. edu/assets / files/Wine-Studies / GregJones/Jones_Bulletin_OIV_2012.pdf (accessed on 12 March 2018).

104. New Zealand Wine. Sustainable Winegrowing New Zealand. Available online: https:/ /www.nzwine.com/ en/sustainability/sustainable-winegrowing-nz (accessed on 17 January 2018).

105. New Zealand Winegrowers. Annual Report 2015; New Zealand Winegrowers: Auckland, New Zealand, 2015.

106. Winetitles. The Australian and New Zealand Wine Industry Directory; Hartley-Higgins: Adelaide, Australia, 2015.

107. Hall, C.M.; Johnson, G. Wine tourism: an imbalanced partnership. In Wine Tourism Perfect Partners, Proceedings of the First Australian Wine Tourism Conference, Margaret River; Dowling, R., Carlsen, J., Eds.; Bureau of Tourism Research: Canberra, Australia, 1998.

108. Christensen, D.; Hall, C.M. 2003 National Wine Tourism Survey: Summary of Results; Research Report; Centre for Tourism, University of Otago: Dunedin, New Zealand, 2004.

109. Deloittes. Vintage 2009 New Zealand Wine Industry Benchmarking Survey; Deloittes and New Zealand Winegrowers: Auckland, New Zealand, 2010.

110. Deloittes. Ripening Opportunities. Wine Industry Benchmarking and Insights 2017 New Zealand; Deloittes, ANZ and New Zealand Winegrowers: Auckland, New Zealand, 2017.

111. Baird, T.; Hall, C.M. Competence based innovation in New Zealand wine tourism: Partial strategies for partial industrialisation. In Competence-Based Innovation in Hospitality and Tourism; Pechlaner, H., Innerhofer, E., Eds.; Routledge: Abingdon, UK, 2016; pp. 197-224. ISBN 9781472463968.

112. Hall, C.M. Innovation and tourism policy in Australia and New Zealand: Never the twain shall meet? J. Policy Res. Tour. Leisure Events 2009, 1, 2-18. [CrossRef]

(C) 2018 by the authors. Licensee MDPI, Basel, Switzerland. This article is an open access article distributed under the terms and conditions of the Creative Commons Attribution (CC BY) license (http:/ / creativecommons.org/licenses/by/4.0/). 